\title{
Microclimate, Body Weight Uniformity, Body Temperature, and Footpad Dermatitis in Broiler Chickens Reared in Commercial Poultry Houses in Hot and Humid Tropical Climates
}

\author{
Damnern Sohsuebngarm ${ }^{1}$, Saijai Kongpechr ${ }^{1}$ and Peerapol Sukon ${ }^{1,2^{*}}$ \\ ${ }^{I}$ Faculty of Veterinary Medicine, Khon Kaen University, Thailand \\ ${ }^{2}$ Research Group for Animal Health Technology, Khon Kaen University, Thailand \\ "Corresponding author's E-mail: sukonp@kku.ac.th; ORCID: 0000-0002-0899-2572
}

\begin{abstract}
The present study was conducted to investigate the variations of microclimate variables along the length of commercial broiler houses and to determine the associations between microclimate variables and animal variables in broiler chickens. A routine rearing program involving 480,000 broiler chickens was conducted in 24 commercial broiler houses (with dimensions of $14 \times 120 \times 2.5 \mathrm{~m}$, yielding $1,680 \mathrm{~m}^{2}$ of rearing area per house). Of these, 6,000 chickens were randomly selected for outcome measurements. Microclimate variables (Ambient Temperature (AT), Relative Humidity (RH), Air Velocity (AV), heat index, effective temperature, and ammonia) and animal variables (body weight uniformity, body temperature, and Footpad Dermatitis (FPD)) were measured at 10 sections (12 m apart) from the proximal end to distal end along the length of each broiler house. Regression analysis was used to determine the pattern of each microclimate variable along the length of the broiler houses and to determine the associations between the microclimate variables and the animal variables. The results showed that AT, heat index, and ammonia linearly increased from the front end to the rear end of the houses. In contrast, RH linearly decreased from the front end to the rear end of the houses. The regression analysis revealed no significant association between any of the microclimate variables and the body weight uniformity. Increasing AT and AV were associated with increasing mean body temperature. Increasing AT was associated with decreasing FPD. However, increasing RH and $\mathrm{AV}$ were associated with increasing FPD. In conclusion, the microclimate variables had various trends along the length of broiler houses.
\end{abstract}

Key words: Body weight uniformity, Broiler house, Footpad dermatitis, Microclimate

\section{INTRODUCTION}

The microclimate surrounding animals is important for livestock production and welfare. It is particularly important for broiler chickens raised under high stock density conditions in commercial broiler houses (Jones et al., 2005). Microclimate variables such as Ambient Temperature (AT), Relative Humidity (RH), and Air Velocity (AV) influence the production, health, and welfare of broiler chickens (Yahav et al., 2001; Andrade de Oliveira et al., 2006; Purswell et al., 2012; Tullo, et al., 2017). In addition, the microclimate in a broiler house is influenced by the outside environment (Kic, 2016). This influence is noticeable in the hot and humid weather of tropical regions, where the AT may exceed 40 ${ }^{\circ} \mathrm{C}$ in the hot season. Chickens exhibit good performance in an optimal temperature environment (also called the thermoneutral zone). The optimal temperature varies depending on the age of the chicken, being approximately $33-35{ }^{\circ} \mathrm{C}$ for one-day-old chicks and decreasing gradually over time to $18-21{ }^{\circ} \mathrm{C}$ just before catch (Bayraktar et al., 2004). Temperatures outside these ranges may affect the production.

Therefore, to fulfill the need for an optimal microclimate for commercial broiler chickens, their houses are designed as closed systems and equipped with tunnel ventilation systems. A house must be large enough for costeffective operation. Typically, a $14 \times 120 \mathrm{~m}$ (width $\times$ length) house can be used to raise 20,000 broiler chickens (with a stocking density of approximately 12 chicks $/ \mathrm{m}^{2}$ or $0.08 \mathrm{~m}^{2} / \mathrm{bird}$ ) (Estevez, 2007). In the hot and humid conditions of tropical climates, a cooling pad system is necessary to reduce the AT inside the house (Bayraktar et al., 2004). The cooling pad is located adjacent to an air inlet near the front end of the house, and an exhaust fan is located at the rear end of the house. Thus, fresh air flows from the front end toward the rear end (Bianchi et al., 2015). Many factors are associated with the microclimate in a broiler house. Because a commercial broiler house is very long, the microclimate in the house may vary among different locations (Bianchi et al., 2015). This variation may affect the production, health status, and welfare of broiler chickens. 
Body weight uniformity is an important index in broiler production because high uniformity satisfies the demands of processing plants and the modern market, whereas poor uniformity reduces income and increases waste (Gous, 2017). Footpad dermatitis (FPD) is a contact dermatitis lesion in the chicken's footpad. It is considered as an important welfare indicator for broiler chickens (Kyvsgaard et al., 2013). The objectives of the present study were to determine the patterns of some microclimate variables along the length of commercial broiler houses and to find the associations between some microclimate variables and body weight uniformity, body temperature, and FPD.

\section{MATERIALS AND METHODS}

\section{Ethical approval}

This study was approved by the Animal Ethics Committee of Khon Kaen University (No. 50/60), Thailand.

\section{Study location and environmental conditions}

The current study was conducted at commercial broiler farms in Prakhon Chai District, Buriram Province, northeastern Thailand (Latitude: $14^{\circ} 36^{\prime} 21.31^{\prime \prime} \mathrm{N}$, Longitude: $103^{\circ} 07^{\prime} 14.92^{\prime \prime} \mathrm{E}$ ). This area is approximately $167 \mathrm{~m}$ above sea level. The average annual temperature is $27.0^{\circ} \mathrm{C}$ : the average low is $22.2^{\circ} \mathrm{C}$, and the average high is $33.0^{\circ} \mathrm{C}$. The average annual relative humidity is $75 \%$ : the lowest average humidity is $40 \%$ in February, and the highest average humidity is $96 \%$ in September.

\section{Housing and equipment}

This study was conducted in 24 standard environmentally controlled commercial broiler houses in two large commercial broiler farms. The tunnelventilated, curtain-sided houses were uniform in size, facilities, equipment, and management. The dimensions of each house were $14 \times 120 \times 2.5 \mathrm{~m}$ (width $\times$ length $\times$ height), with a total area of $1,680 \mathrm{~m}^{2}$ (Figure 1). Each house was constructed with a metal sheet roof and insulated ceiling. The lower section of wall was constructed with brick (to a height of $0.46 \mathrm{~m}$ ), and the upper section was constructed of highquality curtains and netting to prevent birds or other animals from entering from outside. The floor was made from concrete cement and was covered with $5 \mathrm{~cm}$ of fresh rice husk for each growing cycle. Each house was equipped with four rows of automatic feeding pans and five rows of drinkers. At the rear end, 10 large exhaust fans (diameter: $1.37 \mathrm{~m}$ ) were installed for ventilation. On both lateral sides near the front end, a total of 120 cooling pads $(0.3 \times 1.8 \mathrm{~m})$ with a water-supply system were used for cooling the air at the inlet. For lighting, two rows of 18 -watt neon lights were used. For the first three days, black plastic bags were used as supplementary feeding trays to increase the feeding area. Two heaters $(225,000$ British thermal unit) with thermostat sensors were used for heat control.

Figure 1. Dimensions of commercial broiler houses and sampling sections (1-10)

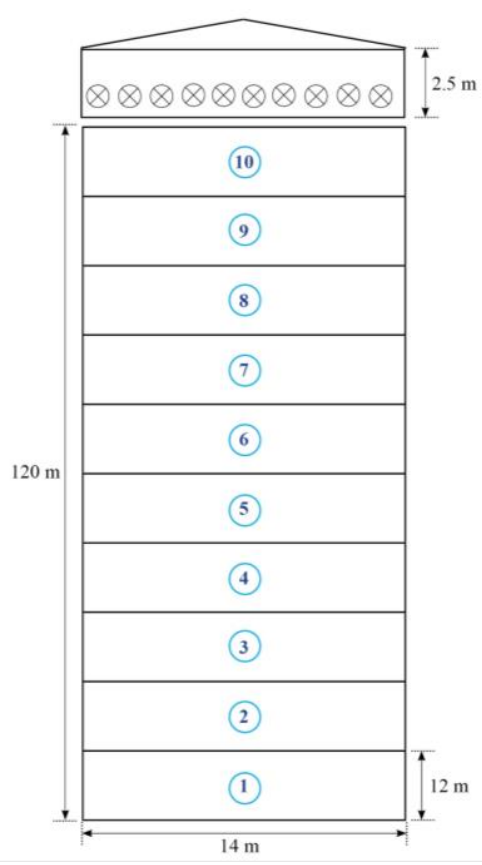
for microclimate and broiler chicken measurements in Buriram Province, Thailand during April-May in 2017 and 2018

\section{Animals}

This study involved 480,000 broiler chickens from 24 commercial broiler houses. The stocking density was approximately 20,000 chickens per house (approximately 12 chickens $/ \mathrm{m}^{2}$ ). A total of 6,000 broiler chickens were individually measured for body weight and body temperature. These chickens included 2,000 Cobb 500 (1,000 males and 1,000 females), 2,000 Ross 308 (1,000 males and 1,000 females), and 2,000 Arbor Acres Plus chickens (1,000 males and 1,000 females). Each house contained one breed with both sexes.

\section{Management}

A similar routine management program for commercial broiler production was used in all study houses. Three feed formulas were used: a starter feed from days 1 to 21, a grower feed from days 22 to 32, and a finisher feed from days 33 until catching. The ingredients of each feed formula are provided in table 1. Each chick was vaccinated against New Castle disease virus and infectious bronchitis under a routine program. Feed and water were supplied ad libitum throughout the rearing period. The ratio of dark to light hours was 23:1 for the first five days of age and the last three days before catching and was 18:6 for the remaining time. The temperature in the house was controlled to meet the optimal conditions for the age of the chickens according to the guidelines for commercial broiler breeds by using heaters or the tunnel ventilation system depending on chicken age. 
Table 1. Ingredients ( $\%$ as fed basis) and composition of diet for broiler chickens at different ages in Buriram Province, Thailand during April-May in 2017 and 2018

\begin{tabular}{|c|c|c|c|}
\hline Ingredients & $\begin{array}{c}\text { Starter } \\
\text { 1-21 days }\end{array}$ & $\begin{array}{c}\text { Grower } \\
\text { 22-32 days }\end{array}$ & $\begin{array}{c}\text { Finisher } \\
33 \text { caught }\end{array}$ \\
\hline Maize & 55.62 & 60.88 & 63.16 \\
\hline Soya bean & 15.19 & 18.05 & 19.58 \\
\hline Soya bean meal & 24.07 & 16.62 & 12.86 \\
\hline Mono-Dicalcium P21 & 1.91 & 1.15 & 1.06 \\
\hline Dicalcium phosphate & 1.53 & 1.76 & 1.81 \\
\hline DL-Methionine (Alimet) & 0.39 & 0.35 & 0.33 \\
\hline L-Lysine & 0.19 & 0.20 & 0.21 \\
\hline Choline Chloride & 0.08 & 0.08 & 0.08 \\
\hline Mineral Premix Broiler & 0.40 & 0.40 & 0.40 \\
\hline Vitamins Premix (Ronozyme Proact) & 0.10 & 0.10 & 0.10 \\
\hline Sodium chloride & 0.42 & 0.40 & 0.40 \\
\hline Toxins binder (Mycrofix SECURE) & 0.10 & - & - \\
\hline Enzyme Phytase (Finase; EC5 L/AXTRA) & - & 0.01 & 0.01 \\
\hline Total & 100 & 100 & 100 \\
\hline \multicolumn{4}{|l|}{ Chemical compositions } \\
\hline Crude protein $(\%)$ & 21.25 & 19.25 & 18.25 \\
\hline Metabolizable energy (Kcal/kg) & 3,016 & 3,110 & 3,150 \\
\hline Calcium $(\%)$ & 1.05 & 1.00 & 1.00 \\
\hline Available Phosphorous (g/kg) & 0.65 & 0.65 & 0.65 \\
\hline
\end{tabular}

\section{Study design, sampling, outcome measurement, and data collection}

The study was conducted in April-May (the warmest months in Thailand) in 2017 and 2018. The length of each broiler house was divided into 10 sections (at $12 \mathrm{~m}$ intervals) starting from the front end to the rear end (Figure 1). In the middle of each section, 25 male or 25 female broiler chickens were randomly selected for outcome measurement. Measurements of microclimate variables and animal variables were done when the chickens were aged 28 and 37 days. All measurements were made at animal height (approximately $30 \mathrm{~cm}$ from the floor). A Kestrel 3000 anemometer (Nielsen-Kellerman Company, Pennsylvania, USA) was used to measured AT, RH, AV, and Heat Index (HI). An ammonia gas detector (Smart Sensor AR 8500, Shenzhen Arco Science \& Technology Co. Ltd, Guangdong, China) was used to measure the ammonia (NH3) level. Effective Temperature (ET) (temperature felt by the bird) was calculated by using the following formula (Bayraktar et al., 2004):

$\mathrm{Y}=0.77531+0.71136 \mathrm{DBT}+0.13181 \mathrm{RH}-3.6814 \mathrm{~A}$

$\mathrm{Y}=$ effective temperature $\left({ }^{\circ} \mathrm{C}\right) ; \mathrm{DBT}=\operatorname{dry}$ bulb temperature $\left({ }^{\circ} \mathrm{C}\right) ; \mathrm{RH}=$ relative humidity $(\%) ; \mathrm{AV}=$ air velocity $(\mathrm{m} / \mathrm{s})$

Individual body weight was measured using a digital scale and body temperature was measured via the cloaca using a digital thermometer. FPD was initially determined using a 0 -3rating scale $(0=$ no lesion, $1=$ small lesion, $2=$ mild lesion, and $3=$ large lesion). However, for ease of interpretation, the scale was redefined such that 0 represented the absence of FPD, and 1 represented the presence of FPD. The prevalence of FPD at each section along the broiler house length was determined.

\section{Statistical analysis}

The normality of continuous variables was assessed by graphic visualization and the Shapiro-Wilk test. Mean Body Weight $(\mathrm{MBW})$ and Mean Body Temperature (MBT) were calculated from individual animals in each section. The coefficient of variation (CV) of MBW, considered as the index of body weight uniformity of broiler chicken flocks along the length of a commercial broiler house, was calculated as the standard deviation of body weight divided by the mean and multiplied by 100 (Gous, 2017). Regression analysis was used to assess the variations of microclimate variables along the length of a commercial broiler house. Univariate and multivariate linear regression analyses were used to find the associations between animal variables and microclimate variables. In the multivariable linear regression, backward elimination was used to obtain the final model. Tolerance and the variance inflation factor were used to assess the multicollinearity of the microclimate variables. Subgroup analysis was used to assess differences in animal variables among subgroups (of chicken age, breed, sex, and year of data collection). The subgroup analyses were performed with analysis of variance (ANOVA) and the Tukey HSD test for multiple comparisons. SPSS version 17 (SPSS Inc., Chicago, IL, USA) was used for all statistical analyses. The significant level was set at a p-value of $<0.05$.

\section{RESULTS}

\section{Patterns of microclimate and animal variables along the length of a commercial broiler house}

The microclimate variables exhibited various trends along the length of the broiler house (Table 2). The AT slightly increased from $27.7{ }^{\circ} \mathrm{C}$ at the front end to $29.8{ }^{\circ} \mathrm{C}$ at the rear end of the house $(\mathrm{P}<0.001)$. The HI and NH3 exhibited similar patterns. HI increased from $32.6{ }^{\circ} \mathrm{C}$ at the front end to $35.7{ }^{\circ} \mathrm{C}$ at the rear end $(\mathrm{P}<0.001)$. $\mathrm{NH} 3$ increased from $0.8 \mathrm{ppm}$ at the front end to $2.5 \mathrm{ppm}$ at the rear end $(\mathrm{p}<0.001)$. In contrast, RH slightly decreased from $83.8 \%$ at the front end to $77.8 \%$ at the rear end $(\mathrm{p}<0.001)$. Although the test for a linear trend of the ET was significant, mean ET values of sections 3 and 4 were lower than those of sections 1 and 2; the mean was then linearly increased from sections 5 through 10. There was no significant linear trend of AV along the length of the broiler house $(\mathrm{P}=0.278)$. None of the animal variables exhibited significant linear trends (Table 2). The Mean CV of MBT was $7.0 \pm 1.4 \%$ in section 4 and $7.7 \pm 1.7 \%$ in section 5. The Mean MBT was largely stable across the length of the house (ranged between $41.4 \pm 0.5^{\circ} \mathrm{C}$ to $41.6 \pm 0.4^{\circ} \mathrm{C}$ ). The prevalence of FPD ranged from $54.8 \pm 32 \%$ to $61.7 \pm 32.2 \%$. 
Table 2. Microclimate variables and variables measured from broiler chickens along the lengths of commercial broiler houses in Buriram Province, Thailand during April-May in 2017 and 2018

\begin{tabular}{|c|c|c|c|c|c|c|c|c|c|c|c|c|}
\hline \multirow{2}{*}{ Variable } & \multicolumn{10}{|c|}{ Sampling section Mean (SD) } & \multicolumn{2}{|c|}{ Test for linear trend } \\
\hline & 1 & 2 & 3 & 4 & 5 & 6 & 7 & 8 & 9 & 10 & B (95\% CI) & p-value \\
\hline \multicolumn{13}{|c|}{ Microclimate variables } \\
\hline $\operatorname{AT}\left({ }^{\circ} \mathrm{C}\right)$ & $27.7(1.9)$ & $27.7(1.8)$ & $28.1(1.8)$ & $28.2(1.9)$ & $28.5(1.8)$ & $28.7(1.8)$ & $28.9(1.8)$ & $29.3(1.9)$ & $29.4(1.9)$ & $29.8(1.9)$ & $0.24(0.15,0.32)$ & $<0.001$ \\
\hline $\mathrm{RH}(\%)$ & $83.8(6.4)$ & $83.6(5.6)$ & $83.0(5.5)$ & $82.1(5.2)$ & $81.0(5.2)$ & $80.9(5.0)$ & 80.7 (4.6) & $80.4(4.9)$ & $79.4(4.0)$ & $77.8(4.5)$ & $-0.61(-0.83,-0.38)$ & $<0.001$ \\
\hline $\mathrm{HI}\left({ }^{\circ} \mathrm{C}\right)$ & $32.6(4.2)$ & $32.7(4.1)$ & $32.7(3.8)$ & $33.4(4.2)$ & $33.8(4.3)$ & $34.1(4.2)$ & $34.6(4.5)$ & $35.2(4.7)$ & $35.3(5.3)$ & $35.7(5.1)$ & $0.38(0.19,0.53)$ & $<0.001$ \\
\hline $\mathrm{AV}(\mathrm{m} / \mathrm{s})$ & $1.4(0.7)$ & $1.9(0.6)$ & $2.2(0.7)$ & $2.2(0.7)$ & $2.2(0.8)$ & $2.1(0.7)$ & $2.0(0.7)$ & $2.0(0.7)$ & $1.9(0.6)$ & $1.9(0.6)$ & $0.02(-0.01,0.05)$ & 0.278 \\
\hline $\mathrm{ET}\left({ }^{\circ} \mathrm{C}\right)$ & $25.2(2.4)$ & $24.1(2.4)$ & $23.6(2.0)$ & 23.7 (1.7) & $24.0(1.6)$ & $24.4(1.6)$ & $24.9(1.4)$ & $25.1(1.4)$ & $25.6(1.6)$ & $25.5(1.7)$ & $0.15(0.07,0.23)$ & 0.001 \\
\hline NH3 (ppm) & $0.8(0.4)$ & $0.9(0.3)$ & $0.5(0.6)$ & $0.6(0.7)$ & $0.7(0.8)$ & $0.8(0.9)$ & $1.3(0.4)$ & $2.0(0.5)$ & $2.5(0.8)$ & $2.1(0.6)$ & $0.20(0.17,0.23)$ & $<0.001$ \\
\hline
\end{tabular}

Variables measured from broiler chickens

\begin{tabular}{|c|c|c|c|c|c|c|c|c|c|c|c|c|}
\hline $\mathrm{CV}(\%)$ of $\mathrm{MBW}$ & $7.5(2.3)$ & $7.0(1.4)$ & $7.5(1.7)$ & $7.0(1.4)$ & $7.7(1.7)$ & $7.1(1.3)$ & $7.5(1.7)$ & $7.3(1.2)$ & $7.2(1.4)$ & $7.2(1.3)$ & $0.00(-0.07,0.07)$ & 0.925 \\
\hline $\operatorname{MBT}\left({ }^{\circ} \mathrm{C}\right)$ & $41.5(0.6)$ & $41.4(0.5)$ & $41.5(0.6)$ & $41.5(0.5)$ & $41.5(0.6)$ & $41.5(0.5)$ & $41.5(0.5)$ & $41.5(0.5)$ & $41.5(0.4)$ & $41.6(0.4)$ & $0.01(-0.01,0.03)$ & 0.273 \\
\hline $\begin{array}{l}\text { Prevalence of FPD } \\
(\%)\end{array}$ & $57.3(31.2)$ & $54.8(32.0)$ & $56.7(32.9)$ & $54.8(31.5)$ & $61.3(32.6)$ & $57.0(32.2)$ & $56.9(30.3)$ & $61.7(32.2)$ & $59.2(30.4)$ & $58.0(33.8)$ & $0.39(-1.00,1.78)$ & 0.582 \\
\hline
\end{tabular}

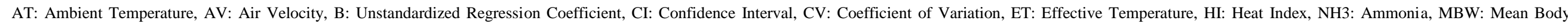
Weight, MBT: Mean Body Temperature, FPD: Foot Pad Dermatitis, RH: Relative Humidity, SD: Standard Deviation 
Linear regression analysis of the associations between microclimate variables and animal variables

The results of the linear regression analyses of the associations between microclimate variables and CV of MBW are presented in table 3. In the univariate analyses, no microclimate variables were significantly associated with the CV of MBW. However, three microclimate variables (AT, RH, and NH3) were retained in the final multivariate model, although they explained only $2.3 \%$ of the variation in the CV of MBW. The results of the linear regression analyses of the associations between microclimate variables and MBT are presented in table 4 . In the univariate analyses, six microclimate variables (AT, RH, HI, AV, NH3, and section) were significantly associated with MBT. Five microclimate variables (AT, RH, HI, AV, and section) were retained in the final multivariate model, which explained $36.3 \%$ of the variation in MBT. Accounting for these five microclimate variables, increasing AT or AV was significantly associated with increasing MBT; in contrast, decreasing RH or HI was associated with increasing MBT. MBT significantly decreased from the front end to the rear end of the house after accounting for AT, RH, HI, and AV. The results of the linear regression analyses of the associations between microclimate variables and the prevalence of FPD are shown in table 5. In the univariate analyses, four microclimate variables (AT, RH, HI, and AV) were significantly associated with the prevalence of FPD. Five microclimate variables (AT, RH, HI, AV, and section) were retained in the final multivariate model. All of these five microclimate variables were significantly associated with the prevalence of FPD. The prevalence of FPD increased as AT decreased after accounting for RH, HI, AV, and section. In contrast, the prevalence of FPD increased when RH, HI, or AV increased after accounting for all of the microclimate variables retained in the final model.

Table 3. Linear regression analysis of the associations between microclimate variables and the coefficient of variation of the mean body weight of broiler chickens in Buriram Province, Thailand during April-May in 2017 and 2018

\begin{tabular}{lcccccc}
\hline Variable & $\begin{array}{c}\text { Univariate analysis, } \\
\text { Estimate }(\mathbf{9 5 \%} \mathbf{C I})\end{array}$ & p-value & $\begin{array}{c}\text { Multivariate analysis } \\
\text { Estimate }(\mathbf{9 5 \%} \mathbf{C I})\end{array}$ & p-value & Tolerance & VIF \\
\hline AT $\left(\mathrm{C}^{\circ}\right)$ & $0.05(-0.04,0.15)$ & 0.346 & $0.11(-0.01,0.22)$ & 0.061 & 0.78 \\
RH $(\%)$ & $-0.04(-0.07,0.00)$ & 0.051 & $-0.06(-0.10,-0.01)$ & 0.008 & 0.81 & 1.28 \\
HI $\left(\mathrm{C}^{\circ}\right)$ & $-0.00(-0.05,0.04)$ & 0.902 & -- & -- & -- & -- \\
AV $(\mathrm{m} / \mathrm{s})$ & $-0.09(-0.37,0.20)$ & 0.545 & -- & -- & -- & - \\
ET $\left(\mathrm{C}^{\circ}\right)$ & $0.09(-0.01,0.19)$ & 0.084 & -- & -- & -- \\
NH3 (ppm) & $-0.04(-0.26,0.18)$ & 0.734 & $-0.24(-0.50,0.02)$ & 0.068 & 0.70 & 1.44 \\
sampling section & $-0.00(-0.07,0.07)$ & 0.925 & -- & -- & -- & -- \\
\hline
\end{tabular}

${ }^{1}$ For the multivariate analysis, the dependent variable was the $\mathrm{CV}(\%)$ of Mean Body Weight $(\mathrm{MBW})$ of broiler chickens, constant=8.94, $\mathrm{R}^{2}=0.035$, adjusted $\mathrm{R}^{2}=0.023$, p-value=0.037. AT: Ambient Temperature, AV: Air Velocity, CI: Confidence Interval, CV: Coefficient of Variation, ET: Effective Temperature, HI: Heat Index, NH3: Ammonia, RH: Relative Humidity, VIF: Variance Inflation Factor

Table 4. Linear regression analysis of the associations between microclimate variables and the mean body temperature of broiler chickens in Buriram Province, Thailand during April-May in 2017 and 2018

\begin{tabular}{|c|c|c|c|c|c|c|}
\hline Variable & $\begin{array}{l}\text { Univariate analysis, } \\
\text { Estimate (95\% CI) }\end{array}$ & p-value & $\begin{array}{c}\text { Multivariate analysis }{ }^{1} \text {, } \\
\text { Estimate (95\% CI) }\end{array}$ & p-value & Tolerance & VIF \\
\hline $\operatorname{AT}\left(\mathrm{C}^{\circ}\right)$ & $0.09(0.06,0.12)$ & $<0.001$ & $0.15(0.11,0.20)$ & $<0.001$ & 0.36 & 2.75 \\
\hline $\mathrm{RH}(\%)$ & $-0.03(-0.04,-0.02)$ & $<0.001$ & $-0.05(-0.06,-0.04)$ & $<0.001$ & 0.84 & 1.20 \\
\hline $\mathrm{HI}\left(\mathrm{C}^{\circ}\right)$ & $0.01(0.00,0.03)$ & 0.043 & $-0.03(-0.04,-0.01)$ & 0.002 & 0.45 & 2.23 \\
\hline $\mathrm{AV}(\mathrm{m} / \mathrm{s})$ & $0.21(0.12,0.30)$ & $<0.001$ & $0.14(0.06,0.21)$ & 0.001 & 0.85 & 1.18 \\
\hline $\operatorname{ET}\left(\mathrm{C}^{\circ}\right)$ & $0.02(-0.02,0.05)$ & 0.360 & -- & -- & -- & -- \\
\hline NH3 (ppm) & $0.11(0.04,0.18)$ & 0.002 & -- & -- & -- & -- \\
\hline sampling section & $0.01(-0.01,0.03)$ & 0.273 & $-0.43(-0.06,-0.02)$ & $<0.001$ & 0.74 & 1.34 \\
\hline
\end{tabular}

${ }^{1}$ For the multivariable analysis, the dependent variable was Mean Body Temperature $(\mathrm{MBT})$ of broiler chickens, constant $=41.67$, $\mathrm{R}^{2}=0.377$, adjusted $\mathrm{R}^{2}=0.363$, p-value $\leq 0.001$. AT: Ambient Temperature, AV: Air Velocity, CI: Confidence Interval, ET: Effective Temperature, HI: Heat Index, NH3: Ammonia, RH: Relative Humidity, VIF: Variance Inflation Factor

Table 5. Linear regression analysis of the associations between microclimate variables and the prevalence of footpad dermatitis among broiler chickens in Buriram Province, Thailand during April-May in 2017 and 2018

\begin{tabular}{lcccccc}
\hline Variable & $\begin{array}{c}\text { Univariate analysis, } \\
\text { Estimate }(\mathbf{9 5 \%} \text { CI) }\end{array}$ & p-value & $\begin{array}{c}\text { Multivariate analysis } \\
\text { Estimate }(\mathbf{9 5 \%} \mathbf{C I})\end{array}$ & p-value & Tolerance & VIF \\
\hline AT $\left(\mathrm{C}^{\circ}\right)$ & $-3.64(-5.65,-1.63)$ & $<0.001$ & $-9.49(-12.53,-6.44)$ & $<0.001$ & 0.36 \\
RH $(\%)$ & $0.75(0.01,1.49)$ & 0.049 & $1.31(0.58,2.04)$ & $<0.001$ & 0.84 & 2.75 \\
HI $\left(\mathrm{C}^{\circ}\right)$ & $-0.90(-1.78,-0.02)$ & 0.046 & $1.24(0.05,2.42)$ & 0.041 & 0.45 & 2.23 \\
AV $(\mathrm{m} / \mathrm{s})$ & $9.51(3.90,15.13)$ & 0.01 & $15.80(10.23,21.36)$ & $<0.001$ & 0.85 & 1.18 \\
ET $\left(\mathrm{C}^{\circ}\right)$ & $-1.48(-3.55,0.60)$ & 0.162 & -- & -- & -- & -- \\
NH3 $(\mathrm{ppm})$ & $-2.69(-7.09,1.71)$ & 0.229 & -- & -- & -- & -- \\
sampling section & $0.39(-1.00,1.78)$ & 0.582 & $2.67(1.23,4.10)$ & $<0.001$ & 0.74 & 1.34 \\
\hline
\end{tabular}

${ }^{1}$ For the multivariable analysis, the dependent variable was the prevalence of Footpad Dermatitis (FPD), constant $=135.26, \mathrm{R}^{2}=0.221$, adjusted $\mathrm{R}^{2}$ $=0.204$, p-value $\leq 0.001$. AT: Ambient Temperature, AV: Air Velocity, CI: Confidence Interval, ET: Effective Temperature, HI: Heat Index, NH3:

Ammonia, RH: Relative Humidity, VIF: Variance Inflation Factor 


\section{Subgroup analyses of animal variables}

The subgroup differences in the animal variables are presented in table 6. There was a significant difference among breeds for the CV of MBW. Ross 308 chickens had a significantly higher mean CV of MBW (7.83\%) compared to Cobb $500(7.01 \%)$ and Arbor Acres Plus chickens (7.05\%). For MBT, three characteristics (age, breed, and year of data collection) were found to differ significantly among subgroups. For the prevalence of FPD, four characteristics (age, breed, sex, and year of data collection) were found to differ significantly among subgroups.

Table 6. Subgroup analyses of the coefficient of variation of prevalence of footpad dermatitis, mean body weight, and mean body temperature of broiler chickens in Buriram Province, Thailand during April-May in 2017 and 2018

\begin{tabular}{|c|c|c|c|c|}
\hline \multirow{2}{*}{\multicolumn{2}{|c|}{ Characteristic and Subgroups }} & \multicolumn{3}{|c|}{ Animal variable Mean $(95 \%$ CI) } \\
\hline & & $\mathrm{CV}(\%)$ of $\mathrm{MBW}$ & $\operatorname{MBT}\left(\mathrm{C}^{\circ}\right)$ & Prevalence of FPD (\%) \\
\hline \multirow{2}{*}{ Age } & 28 days & $7.48(7.21,7.75)$ & $41.60(41.55,41.66)^{\mathrm{a}}$ & $51.35(46.88,55.82)^{\mathrm{a}}$ \\
\hline & 37 days & $7.11(6.84,7.38)$ & $41.41(41.36,41.47)^{\mathrm{b}}$ & $64.17(59.70,68.64)^{\mathrm{b}}$ \\
\hline \multirow{3}{*}{ Breed } & Cobb 500 & $7.01(6.68,7.34)^{\mathrm{a}}$ & $41.34(41.28,41.41)^{\mathrm{a}}$ & $44.65(39.17,50.13)^{\mathrm{a}}$ \\
\hline & Ross 308 & $7.83(7.50,8.17)^{\mathrm{b}}$ & $41.67(41.60,41.74)^{\mathrm{b}}$ & $58.22(52.75,63.70)^{\mathrm{b}}$ \\
\hline & Arbor Acres Plus & $7.05(6.71,7.38)^{\mathrm{a}}$ & $41.51(41.44,41.58)^{\mathrm{c}}$ & $70.40(64.92,75.88)^{\mathrm{c}}$ \\
\hline \multirow{2}{*}{ Sex } & Male & $7.31(7.04,7.58)$ & $41.55(41.50,41.61)$ & $51.60(47.13,56.07)^{\mathrm{a}}$ \\
\hline & Female & $7.28(7.01,7.56)$ & $41.46(41.41,41.52)$ & $63.92(59.45,68.39)^{\mathrm{b}}$ \\
\hline \multirow{2}{*}{ Year } & 2017 & $7.40(7.13,7.67)$ & $41.87(41.81,41.92)^{\mathrm{a}}$ & $44.03(39.56,48.51)^{\mathrm{a}}$ \\
\hline & 2018 & $7.19(6.92,7.47)$ & $41.15(41.10,41.21)^{\mathrm{b}}$ & $71.48(67.01,75.96)^{\mathrm{b}}$ \\
\hline
\end{tabular}

${ }^{\mathrm{abc}}$ For a given characteristic, different superscripts within a column indicate a significant difference. Tukey HSD test was used for multiple comparisons. CV: Coefficient of Variation, MBW: Mean Body Weight, MBT: Mean Body Weight, FPD: Footpad Dermatitis

\section{DISCUSSION}

The current study revealed that the different microclimate variables had various trends along the lengths of commercial broiler houses. The AT, HI, and NH3 gradually increased from the front end to the rear ends of the houses. However, RH gradually decreased from the front end to the rear end. Microclimate variables such as AT, RH, and AV are very important to bird health and welfare because they facilitate heat transfer between the birds and the surrounding environment. Chickens are homeothermic animals and have an internal body temperature between $39{ }^{\circ} \mathrm{C}$ and $42.2{ }^{\circ} \mathrm{C}$ (Oloyo, 2018). As homeotherms, these birds must constantly maintain their body temperature under fluctuating microclimate conditions. The AT, RH, and AV are combined into an index called the Temperature-Humidity-Velocity Index (THVI), which is a well-known index for determining the ET (Tao and Xin, 2003).

The AT in the current study gradually increased from $27.7^{\circ} \mathrm{C}$ at the front end of the house to $29.8{ }^{\circ} \mathrm{C}$ at the rear end of the house. This increase may be explained by the fact that the front end of the house is located closer to the cooling pad than is the rear end. In addition, the heat produced by the birds moves from the front end to the rear end according to the direction of air ventilation. Bianchi et al. (2015) also found that temperature slightly increased from the front end to the rear end of a tunnel-ventilated broiler house. In addition, AT has been found to fluctuate during the day (Bayraktar et al., 2004). Heat transfer is more effective when AT is lower than the bird's body temperature. In this situation, metabolic heat produced by the bird is dissipated through sensible heat loss by conduction and convection (Oloyo, 2018). In the present study, the AT was considerably higher than the recommended temperature $\left(21^{\circ} \mathrm{C}\right)$ by the breeder company. Additionally, the ET, although was higher $\left(23.6{ }^{\circ} \mathrm{C}\right.$ to $\left.25.6{ }^{\circ} \mathrm{C}\right)$ than the recommended temperature, was lower than the AT. In hot and humid conditions in the tropics, environmentally controlled broiler houses are preferred over conventional broiler houses for enhancing production and the birds' welfare (Farhadi et al., 2016).

The RH in the current study was high, and it gradually decreased from $83.8 \%$ at the front end of the house to $77.8 \%$ at the rear end. Water evaporation from the cooling pad system near the front end of the house may be responsible for the increased RH in this region. The RH in this study was higher than that reported in the previous studies in Turkey (Bayraktar et al., 2004) and Italy (Bianchi et al., 2015). Bayraktar et al. (2004) evaluated the effectiveness of the pad cooling system in broiler houses under hot weather conditions in Turkey and reported that RH values in May fluctuated between $45 \%$ and $70 \%$. Bianchi et al. (2015) measured microclimate parameters in an industrial broiler house in Italy and reported that $\mathrm{RH}$ was lower than $50 \%$. These values were remarkably lower than the results obtained in the present study. This difference may result from a difference in the outside climate of distinct geographic regions of each study. Optimal RH differs among different ages of broiler chickens. Younger broilers require more humidity than older ones. Very high humidity impedes heat dissipation and may be associated with wet litter (Weaver and Meijerhof, 1991). 
However, in tunnel-ventilated broiler houses, this issue is alleviated by the airflow. In winter in European countries, very low humidity in young chickens may cause problems for bird health (Jones et al., 2005).

The HI is derived from air temperature and RH. Although its formula is complex, HI is a useful indicator of "felt air temperature" or "apparent temperature" (Anderson et al., 2013). At a given air temperature, high humidity results in high $\mathrm{HI}$ and feels hotter or warmer than low humidity. In this study, HI was high (slightly increasing from $32.6{ }^{\circ} \mathrm{C}$ at the front of the broiler house to $35.7{ }^{\circ} \mathrm{C}$ at the rear end), which may be due to the high humidity $(77.8-83.8 \%)$. High air temperature and high humidity may result in heat stress in birds. Under heat stress, chickens may alter their behavior, and heat stress can have adverse effects on their performance (Lara and Rostagno, 2013; Bhadauria et al., 2014). In the present study, the AV helped alleviate heat stress in the broiler house because convection heat loss increases significantly with increasing AV (Yahav et al., 2004).

The AV is an important factor in convectional cooling and helps regulate air quality (Oloyo, 2018). In this study, AV was approximately $1.4 \mathrm{~m} / \mathrm{s}$ to $2.2 \mathrm{~m} / \mathrm{s}$. Under harsh environmental conditions, Yahav et al. (2004) suggested that an $\mathrm{AV}$ of $2.0 \mathrm{~m} / \mathrm{s}$ enabled broiler chickens to maintain proper performance and efficient thermoregulation. May et al. (2000) found that high AV had little effect on the daily patterns of feed and water consumption in broiler chickens. Increasing the AV around broiler chickens is an effective way to improve broiler performance when the temperature is above the thermoneutral zone (May et al., 2000).

The ET may be the best temperature indicator for broiler chickens in a tunnel-ventilated house because it is derived from AT, RH, and AV. In the present study, the ET was approximately $23.6{ }^{\circ} \mathrm{C}$ to $25.6{ }^{\circ} \mathrm{C}$. These values were lower than those of AT (approximately $27.7^{\circ} \mathrm{C}$ to $29.8^{\circ} \mathrm{C}$ ). An ET lower than AT indicated the effectiveness of the AV. However, ET in this study was approximately $2.6{ }^{\circ} \mathrm{C}$ to $4.6{ }^{\circ} \mathrm{C}$ higher than the recommended temperature.

The NH3 concentrations in this study were low, although they gradually increased from $0.8 \mathrm{ppm}$ at the front end of the broiler house to $2.5 \mathrm{ppm}$ near the rear end. NH3 is a gas harmful to broiler health and performance (Beker et al., 2004; Miles et al., 2004). Recent studies indicate that NH3 may suppress the immune response of broiler chickens (Wei et al., 2015) and it alters gene expression in the breast muscle of broiler chickens (Yi et al., 2016). However, the NH3 levels in this study were far lower than the recommended levels (not exceeding $25 \mathrm{ppm}$ ). The low NH3 levels in this study may have resulted from the good ventilation system.

Results from regression analysis in this study indicated no significant associations between the microclimate variables and the body weight uniformity. This may be explained that variations in microclimate variables along the length of the broiler house are not large enough to cause a significant difference in body weight uniformity. However, several factors especially feed and protein contents may have substantial effects on uniformity (Berhe and Gous, 2008; Gous, 2017).

FPD is an important welfare concern in broiler chickens. It is characterized by inflammation on the plantar surface of chickens' footpads and is commonly observed in fast-growing broiler chickens (Shepherd and Fairchild, 2010). Results from this study indicated that many microclimate variables (AT, RH, and AV) were associated with the prevalence of FPD. Increasing RH is associated with increasing prevalence of FPD. This may be explained that high RH may result in more wet litter. Wet litter is known as an important risk factor for FPD in broiler chickens (Mayne 2005; Taira et al., 2014). In addition, nutritional factors may influence the excreta moisture resulting in a wet litter (Collett 2012; Swiatkiewicz et al., 2017).

\section{CONCLUSION}

The present study demonstrated that the different microclimate variables had various trends along the lengths of commercial broiler houses. AT, HI, and NH3 gradually increased from the front end to the rear ends of the houses. However, RH gradually decreased from the front end to the rear end. Further studies should be conducted to better understand the effects of microclimate variables on the prevalence of FPD.

\section{DECLARATIONS}

\section{Acknowledgments}

This study was supported by the Research Group on Toxic Substances in Livestock and Aquatic Animals and the Faculty of Veterinary Medicine, Khon Kaen University.

\section{Authors' contribution}

Damnern, Saijai, and Peerapol participated equally in study design, data collection, data analysis, writing, and approving the final manuscript.

\section{Competing interests}

The authors have declared that no competing interest exists. 


\section{REFERENCES}

Anderson GB, Bell ML and Peng RD (2013). Methods to calculate the heat index as an exposure metric in environmental health research. Environmental Health Perspectives. 121 (10): 1111-1119. DOI: https://doi.org/10.1289/ehp.1206273

Andrade de Oliveira G, Flávia Miranda de Oliveira R, Donzele J, Roberto Cecon P, Gomes Marçal Vieira Vaz R, and Antonio Dias Orlando U (2006). Effect of environmental temperature on performance and carcass characteristics of broilers from 22 to 42 days old. Revista Brasileira de Zootecnia, 35: 1398-1405. DOI: http://dx.doi.org/10.1590/S1516-35982006000500020

Bayraktar Ö Artukoglu M and Altan A (2004). Evaluation of the pad cooling system effectiveness used in hot weather conditions in broiler houses: Izmir case study. Hayvansal Üretim, 45: 1-9. Available at: https://dergipark.org.tr/download/article-file/85134

Beker A, Vanhooser SL, Swartzlander JH and Teeter RG (2004). Atmospheric ammonia concentration effects on broiler growth and performance. The Journal of Applied Poultry Research, 13 (1): 5-9. DOI: https://doi.org/ 10.1093/japr/13.1.5

Berhe ET and Gous RM (2008). Effect of dietary protein content on growth, uniformity and mortality of two commercial broiler strains. South African Journal of Animal Sciences, 38: 293-302. Available at: http://www.scielo.org.za/scielo.php?script=sci_arttext\&pid=S0375-15892008000400003

Bhadauria P, Kataria JM, Majumdar S, Bhanja SK, Divya and Kolluri G (2014). Impact of hot climate on poultry production system-a review. Journal of Poultry Science and Technology, 2: 56-63. Available at: https://www.researchgate.net/publication/315337840_Impact_of_Hot_Climate_on_Poultry_Production_System-A_Review

Bianchi B, Giametta F, La Fianza G, Gentile A and Catalano P (2015). Microclimate measuring and fluid-dynamic simulation in an industrial broiler house: Testing of an experimental ventilation system. Veterinaria Italiana, 51 (2): 85-92. DOI: https://doi.org/10.12834/VetIt.689.5112.03

Collett SR (2012). Nutrition and wet litter problems in poultry. Animal Feed Science and Technology, 173 (1): 65-75. DOI: https://doi.org/10.1016/j.anifeedsci.2011.12.013

Estevez I (2007). Density allowances for broilers: Where to set the limits? Poultry Science, 86 (6): 1265-1272. DOI: https://doi.org/10.1093/ps/86.6.1265

Farhadi D, Hosseini SM and Dezfuli BT (2016). Effect of house type on growth performance, litter quality and incidence of foot lesions in broiler chickens reared in varying stocking density. Journal of BioScience \& Biotechnology, 5 (1): 69-78. Available at: http://www.jbb.uniplovdiv.bg/documents/27807/1703624/jbb_2016-5\%281\%29-pages_69-78.pdf

Gous RM (2017). Nutritional and environmental effects on broiler uniformity. World's Poultry Science Journal, 74 (1): 21-34. DOI: https://doi.org/10.1017/S0043933917001039

Jones TA, Donnelly CA and Dawkins MS (2005). Environmental and management factors affecting the welfare of chickens on commercial farms in the United Kingdom and Denmark stocked at five densities. Poultry Science, 84 (8): 1155-1165. DOI: https://doi.org/10.1093/ps/84.8.1155

Kic P (2016). Microclimatic conditions in the poultry houses. Agronomy Research, 14 (1): 82-90. Available at: https://www.researchgate.net/publication/303787368_Microclimatic_conditions_in_the_poultry_houses

Kyvsgaard NC, Jensen HB, Ambrosen T and Toft N (2013). Temporal changes and risk factors for foot-pad dermatitis in danish broilers. Poultry Science, 92 (1): 26-32. DOI: https://doi.org/10.3382/ps.2012-02433

Lara LJ and Rostagno MH (2013). Impact of heat stress on poultry production. Animals, 3 (2): 356-369. DOI: https://doi.org/10.3390/ani3020356

May JD, Lott BD and Simmons JD (2000). The effect of air velocity on broiler performance and feed and water consumption. Poultry Science, 79 (10): 1396-1400. DOI: https://doi.org/10.1093/ps/79.10.1396

Mayne RK (2005). A review of the aetiology and possible causative factors of foot pad dermatitis in growing turkeys and broilers. World's Poultry Science Journal, 61 (2): 256-267. DOI: https://doi.org/10.1079/WPS200458

Miles DM, Branton SL and Lott BD (2004). Atmospheric ammonia is detrimental to the performance of modern commercial broilers. Poultry Science, 83 (10): 1650-1654.DOI: https://doi.org/10.1093/ps/83.10.1650

Oloyo A (2018). The use of housing system in the management of heat stress in poultry production in hot and humid climate: a review. Poultry Science Journal, 6 (1): 1-9. DOI: https://doi.org/10.22069/psj.2018.13880.1284

Purswell J, Dozier W, Olanrewaju H, Davis JD, Xin H and Gates R (2012). Effect of temperature-humidity index on live performance in broiler chickens grown from 49 to 63 days of age. Conference: 2012 IX International Livestock Environment Symposium (ILES IX). DOI: https://doi.org/10.13031/2013.41619

Shepherd EM and Fairchild BD (2010). Footpad dermatitis in poultry. Poultry Science, 89 (10): 2043-2051. DOI: https://doi.org/10.3382/ps.201000770

Swiatkiewicz S, Arczewska-Wlosek A and Jozefiak D (2017). The nutrition of poultry as a factor affecting litter quality and foot pad dermatitis - an updated review. Journal of Animal Physiology and Animal Nutrition, 101 (5): e14-e20. DOI: https://doi.org/10.1111/jpn.12630

Taira K, Nagai T, Obi T and Takase K (2014). Effect of litter moisture on the development of footpad dermatitis in broiler chickens. The Journal of Veterinary Medical Science, 76 (4): 583-586. DOI: https://doi.org/10.1292/jvms.13-0321

Tao X and Xin H (2003). Temperature-humidity-velocity index for market- size broilers. DOI: https://doi.org/10.13031/2013.14094

Tullo E, Fontana I, Pena Fernandez A, Vranken E, Norton T, Berckmans D and Guarino M (2017). Association between environmental predisposing risk factors and leg disorders in broiler chickens, Journal of Animal Science , 95 (4): 1512-1520. DOI: https://doi.org/10.2527/jas.2016.1257

Weaver WD Jr and Meijerhof R (1991). The effect of different levels of relative humidity and air movement on litter conditions, ammonia levels, growth, and carcass quality for broiler chickens. Poultry Science, 70 (4): 746-755. DOI: https://doi.org/10.3382/ps.0700746

Wei FX, Hu XF, Xu B, Zhang MH, Li SY, Sun QY and Lin P (2015). Ammonia concentration and relative humidity in poultry houses affect the immune response of broilers. Genetics and Molecular Research, 14 (2): 3160-3169. DOI: https://doi.org/10.4238/2015.April.10.27

Yahav S, Straschnow A, Luger D, Shinder D, Tanny J and Cohen S (2004). Ventilation, sensible heat loss, broiler energy, and water balance under harsh environmental conditions. Poultry Science, 83 (2): 253-258. DOI: https://doi.org/10.1093/ps/83.2.253

Yahav S, Straschnow A, Vax E, Razpakovski V and Shinder D (2001). Air velocity alters broiler performance under harsh environmental conditions. Poultry Science, 80 (6): 724-726. DOI: https://doi.org/10.1093/ps/80.6.724

Yi B, Chen L, Sa R, Zhong R, Xing H and Zhang H (2016). High concentrations of atmospheric ammonia induce alterations of gene expression in the breast muscle of broilers (Gallus gallus) based on RNA-seq. BMC Genomics, 17 (1): 598-598. DOI: https://doi.org/10.1186/s12864-016-2961-2 